\title{
Hydrogeochemical features of groundwater resources in Tabriz plain, northwest of Iran
}

\author{
Rahim Barzegar ${ }^{1} \cdot$ Asghar Asghari Moghaddam ${ }^{1} \cdot$ Evangelos Tziritis $^{2}$
}

Received: 15 July 2016/ Accepted: 21 February 2017/Published online: 4 March 2017

(c) The Author(s) 2017. This article is published with open access at Springerlink.com

\begin{abstract}
The present study seeks to evaluate the hydrogeochemistry of Tabriz plain in NW Iran, through major ion chemistry and their spatial variations. In order to accomplish these, groundwater sampling from 30 shallow and deep wells in the plain were carried out in July 2012. The water samples were analyzed for various physicochemical parameters such as $\mathrm{pH}, \mathrm{EC}, \mathrm{Na}^{+}, \mathrm{Ca}^{2+}, \mathrm{K}^{+}$, $\mathrm{Mg}^{2+}, \mathrm{Cl}^{-}, \mathrm{CO}_{3}{ }^{2-}, \mathrm{HCO}_{3}{ }^{-}, \mathrm{SO}_{4}{ }^{2-}$ and $\mathrm{NO}_{3}{ }^{-}$. Chadha's diagram demonstrates that most of the groundwaters belonged to the $\mathrm{Na}-\mathrm{Cl}$ and mixed $\mathrm{Ca}-\mathrm{Mg}-\mathrm{Cl}$ hydrochemical facies. The concentrations of some major ions in groundwater are above the permissible limit for drinking and domestic purposes except for a few locations. The results of saturation index computation show that dissolution of gypsum, anhydrite, halite and silicate minerals occurs frequently across the study area, whereas the groundwater is supersaturated with regard to calcite and dolomite. Cross-plots show that weathering and dissolution of different rocks and minerals, ion exchange, reverse ion exchange and anthropogenic activities, especially agricultural activities, are effective in hydrogeochemistry of the study area.
\end{abstract}

Keywords Groundwater · Hydrogeochemistry · Saturation index $\cdot$ Tabriz plain $\cdot$ Iran

Rahim Barzegar

rm.barzegar@yahoo.com

1 Department of Earth Sciences, Faculty of Natural Sciences, University of Tabriz, Tabriz, Iran

2 Hellenic Agricultural Organization, Soil and Water Resources Institute, 57400 Sindos, Greece

\section{Introduction}

Groundwater resources are important for the socio-economic development, especially in arid and semi-arid regions (Tlili-Zrelli et al. 2012). Water quality refers to the natural, physical and chemical state of the water as well as any alteration that might have been caused by anthropogenic activity (Venkateswaran et al. 2011; Jafar Ahamed et al. 2013). The groundwater quality, which is normally controlled by variable physicochemical characteristics, is the outcome of all those processes and reactions that act on water from the moment it condenses in the atmosphere till the time it is exploited by a well (Arumugam and Elangovan 2009).

Hydrogeochemical evaluation of groundwater systems is usually based on the availability of a large amount of information concerning groundwater chemistry. Many factors such as climate, soil type, mineralogy of the rock types forming catchments and aquifers, area topography, overlying land uses, source of recharge water, atmospheric inputs, etc., may affect groundwater chemistry (Reghunath et al. 2002; Singh et al. 2004; Tziritis et al., 2016). In addition to these factors, the interaction between surface and groundwaters as well as the groundwater mixing of different origins and characteristics may also have a significant impact on hydrogeochemistry (Reghunath et al. 2002). Groundwater contains many chemical constituents, both natural and man-made. Generally, major ion studies are used to determine hydrochemical facies of waters and the spatial variability of these ions can give insight into aquifer heterogeneity and connectivity as well as into the ongoing hydrogeochemical process of the groundwater system (Belkhiri et al. 2012). Major ion chemistry, in particular molar ion ratios, is useful in assessing the sources of solutes and characterizing hydrogeochemical origin 
and evolution in aquifers (e.g., Cartwright et al. 2004; Currell and Carthwright 2011; Voutsis et al. 2015). The geological history of the aquifers can be obtained from investigation of the groundwater chemistry (Aghazadeh and Asghari Moghaddam 2010; Das and Nag 2015).

Hydrogeochemical assessment of the water systems is of significant importance; especially, in populated regions which depend on groundwater. Tabriz district is one of the most densely populated, active intensively farming and industrial area in the northwest of Iran. Due to scarcity of suitable surface waters, groundwater is the only available water resource which supplies drinking, irrigation and industrial demands of the area. A few studies have been carried out on the hydrogeology and hydrogeochemistry of the area (CITRA-SOGREAH-CCG-HYDRA 1965; ELCELECTRO Consult 1969; Asghri Moghaddam 1991; Asghri Moghaddam and Allaf Najib 2006). Barzegar et al. (2015) reported the occurrence of heavy metals and metalloids such as $\mathrm{Fe}, \mathrm{Cr}, \mathrm{Mn}, \mathrm{Al}$ and $\mathrm{As}$ in the Tabriz plain aquifer. They concluded that the arsenic concentrations in the unconfined aquifer and in the recharge areas of the plain boundary (with an average of $25.8 \mu \mathrm{g} / \mathrm{L}$ ) were lower, than those in the confined aquifer and the deeper wells, which had an average value of $122.5 \mu \mathrm{g} \mathrm{L}^{-1}$. The arsenic occurrence in groundwater resources of the area was attributed to the geological formations such as alluvial tuffs of Sahand Mountain; its concentration is highly dependent on the redox conditions within the aquifer systems and, subsequently on the hydrogeological regime, residence time of water and aquifer depth.

With the above background, the main objectives of this study are: (1) to assess the major ion chemistry of groundwater; (2) to identify the hydrogeochemical processes affecting the groundwater chemistry. The development of groundwater resources in the region is a sensitive issue in environmental and socio-economic terms. Therefore, sustainable management is required to avoid water quality degradation, which depends on detailed knowledge of the groundwater chemistry.

\section{Materials and methods}

\section{Study area}

The Tabriz plain, between the latitudes of $45^{\circ} 30^{\prime}$ and $46^{\circ} 15^{\prime} \mathrm{N}$ and altitudes $37^{\circ} 56^{\prime}$ and $38^{\circ} 17^{\prime} \mathrm{E}$, with an area of more than $700 \mathrm{~km}^{2}$ is extended from the eastern limit of Tabriz city to the salt flats of Urmia Lake in the northwest of Iran. The study area is surrounded by southern slopes of Mishow and Morow and west Garadug Mountains (north), northern slopes of Sahand Mountain (south), Tabriz city (east) and Urmia lake salt marsh lands (west) (Fig. 1). The elevation of the area ranges between 1247 and $3600 \mathrm{~m}$ above sea level. The land surface elevation of the area is highly variable, which represents a more or less uniform geomorphic feature in the plain. Regionally, the area is dipping towards southwest and as a result the movement of water follows a route from northeast to southwest direction. The average annual precipitation is about $230 \mathrm{~mm}$. The highest $(48.2 \mathrm{~mm})$ and lowest $(4 \mathrm{~mm})$ precipitation occurs in the spring and summer seasons, respectively. Monthly averages for precipitation, temperature and humidity are shown in Fig. 2. The average annual temperature in the study area is about $12.8^{\circ} \mathrm{C}$; the temperature often reaches $2.1{ }^{\circ} \mathrm{C}$ in summer and drops below freezing $\left(-0.5^{\circ} \mathrm{C}\right)$ in winter. The maximum and minimum humidity are 69 and 32\%, respectively. The plain lies within the cold and dry climate according to the Emberger (1930) classification (Barzegar 2014; Barzegar et al. 2015, 2016a).

Agriculture and industry are the main human activities in the study area. Industrial activities are relatively intensive in the west of the Tabriz city. Fertilizers that contain nutrients such as nitrogen are used excessively to increase production in the agricultural lands. Numerous factories, including petrochemical, leather tanning, metal smelting and food processing are located in the study area. A large volume of waste water is released from these factories which enter into the Aji-Chay River.

\section{Geology and hydrogeology}

The geology of the study area is relatively complex including in general formations from Devonian to Quaternary ages (Fig. 3). The North Tabriz fault, the most important fault in the area, separates Morow Mountains from the alluvial deposits (Asghri Moghaddam 1991). The Upper Red Formation (Miocene series) is outcropped in the northeast of the Tabriz area and made up of red marls with gypsum, conglomerate, salt and marly limestone's with thickness of up to $1000 \mathrm{~m}$. Pliocene beds are exposed in the east of Tabriz and overlie the Upper Red Formations with normal and undisturbed contact. They consist of lacustrine yellow marl, sandstone with sand and lignite, and grey, blue, greenish clay with so-called "Fish beds" (Barzegar et al. 2015, 2016c).

The Plio-Pleistocene volcanic tuffs have an extended exposure and overlie the Pliocene beds to the south of the Tabriz plain around the core of the Sahand volcano. The formation consists of red and green andesite tuff admixed with large quantities of blocks, boulders, gravel and sand of volcanic and alluvial origin with thickness of up to 500 meters and it has good quality groundwater resources (Barzegar et al. 2015, 2016b). 

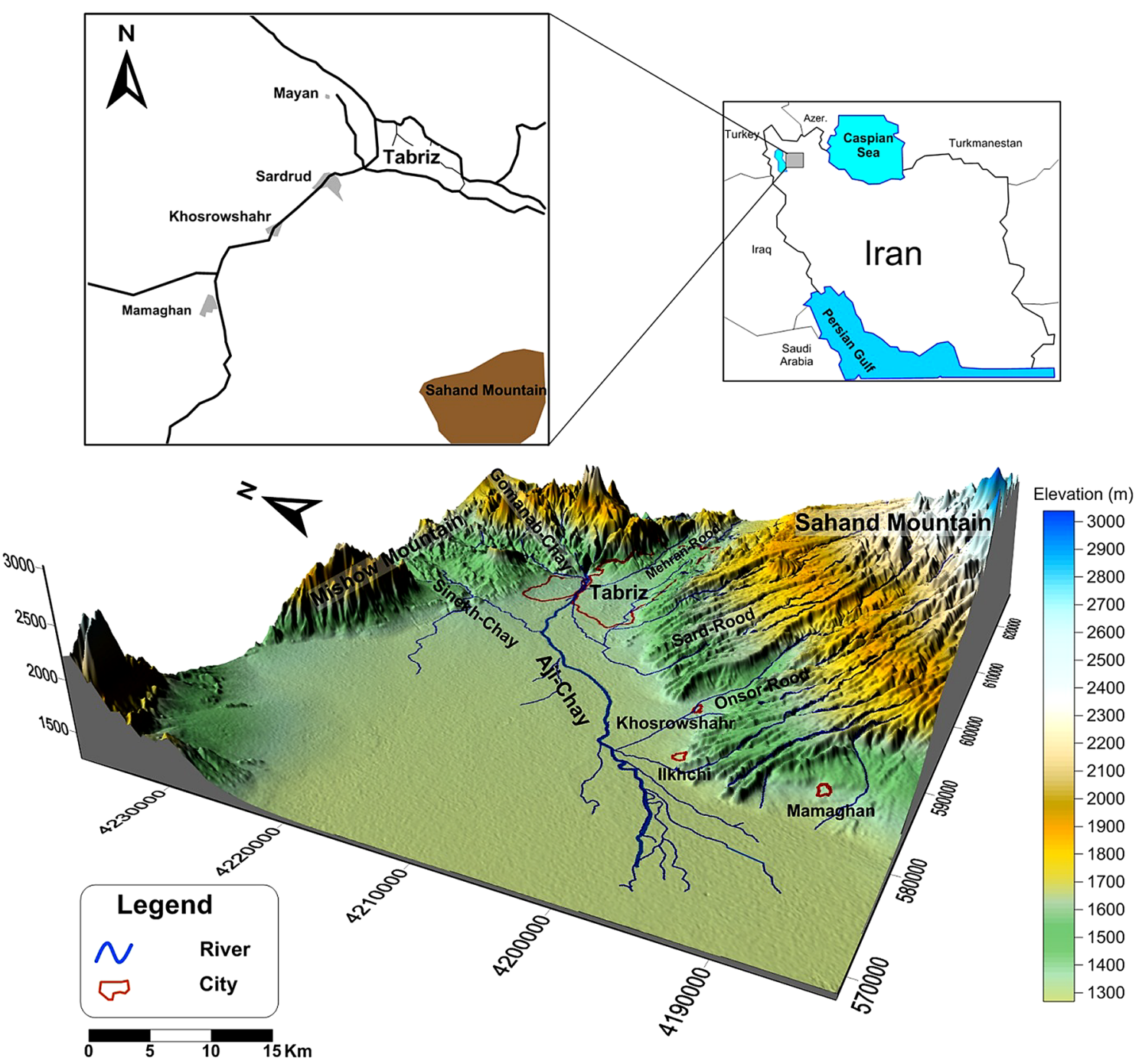

Fig. 1 Location map of the study area and its drainages

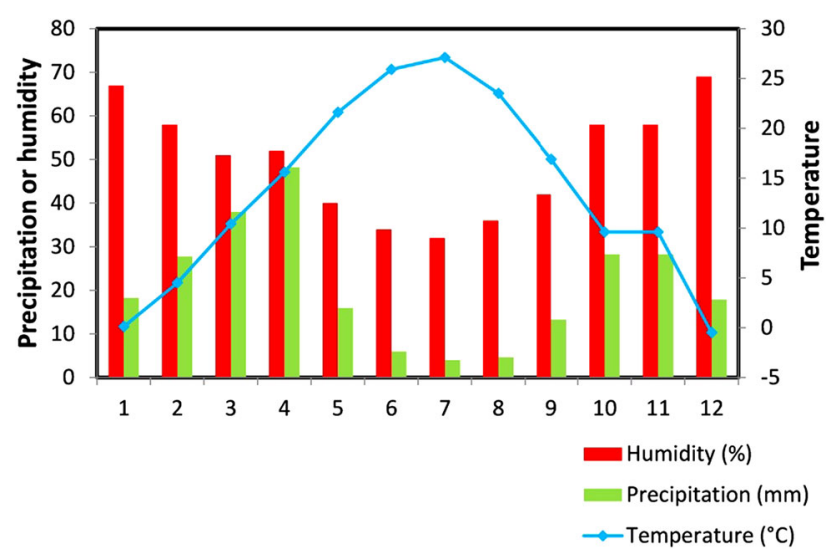

Fig. 2 Monthly averages of precipitation, temperature and humidity

The Quaternary Alluvial deposits dominate in the west of the area. These deposits include alluvium, fans and recent Aji-Chay terraces, which consist of several beds of gravel, sand, silt and clay and become progressively finer and more clayey towards the west of the plain. A simplified stratigraphic sequence in the study area is shown in Fig. 4.

The Aji-Chay River, most important river in the area, enters to the plain from its northwest boundary, and flows along the central part of the plain towards the west, and at the end of the plain eventually discharges to the Urmia Lake (Barzegar et al. 2016d, 2017). The Mehran-Rood River passes inside the Tabriz city and then joins the AjiChay River at the western end of the city. The GomanabChay and Sinekh-Chay Rivers join to the Aji-Chay River from right bank side and the Sard-Rood and Onsor-Rood Rivers from left bank side (Fig. 1). These rivers form alluvial fans at the entrance of the plain (Barzegar and Asghari Moghaddam 2016).

The Aji-Chay, Gomanab-Chay and Sinekh-Chay Rivers cross the Upper Red formations, therefore these rivers transport fine suspended solid materials during the higher 
Fig. 3 Geological map of the study area

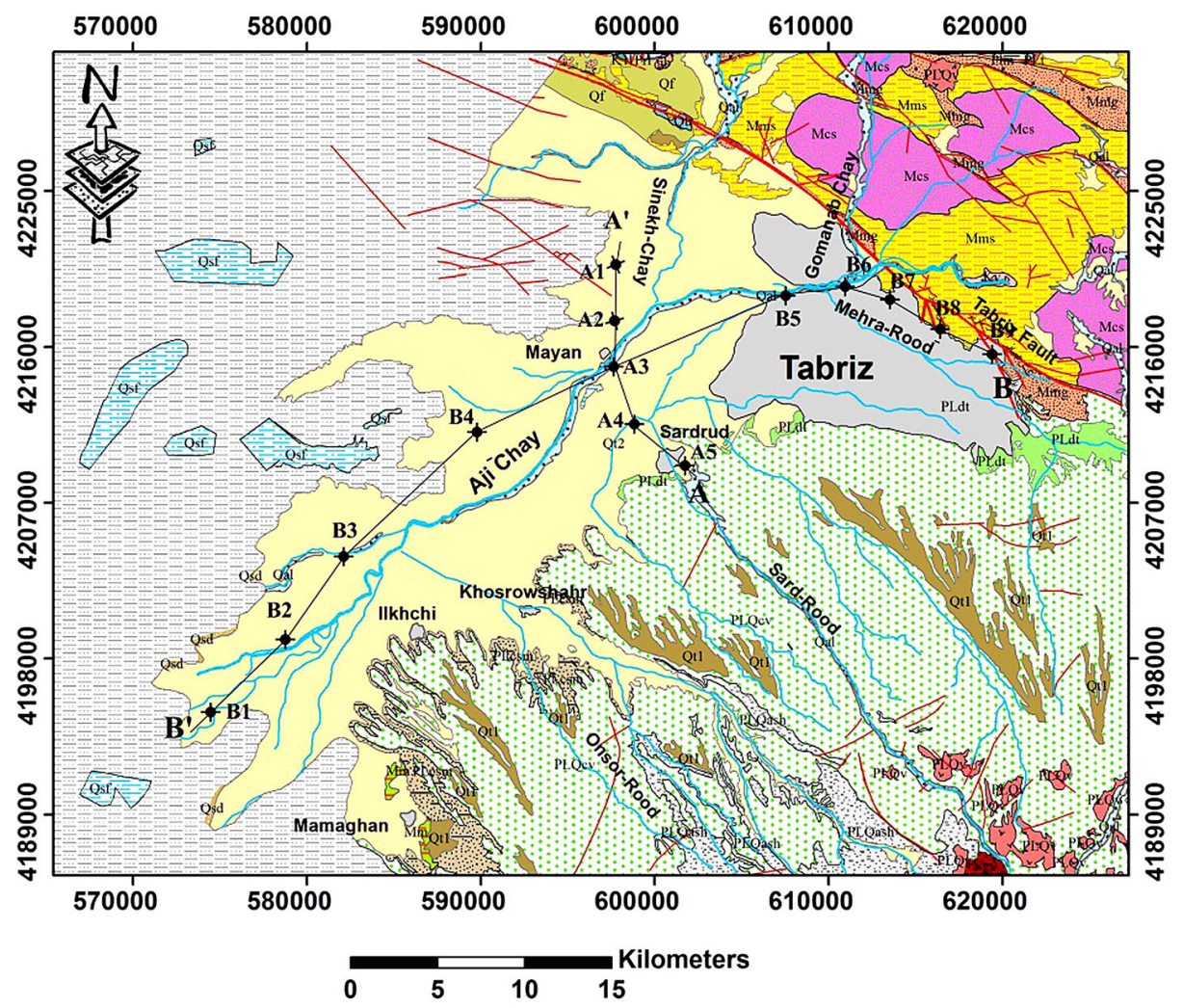

LEGEND

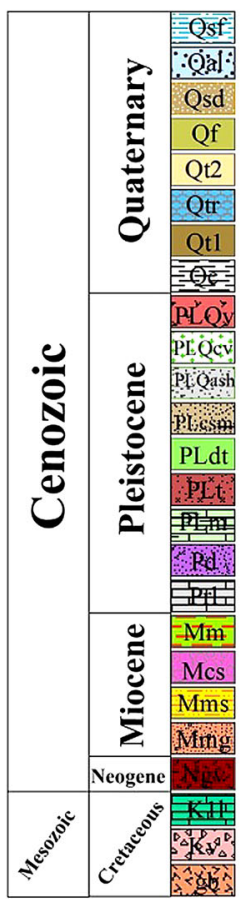

Salt flat

Recent alluvium

Sand dune

Terraces and gravel fans

Younger terraces

Travertine

Older terraces

Clay flat

Trachyandesite volcanic dome and volcanic breccia

Conglomerate with lahar, tuff, pumice and volcanic ashes

Volcanic ashes with block, lahar and welded breccia

Alternation of marle, sandstone and conglomerate

Fine clastic sediments, tuff with diatomite and fishbed

Alternation of tuff and brecciated lava

Alternation of green marl and limestone with chert nodules

White to violet quartz sandstone

Grey limestone

Red marl

Red conglomerate with alternation of sandstone and marl

Red marl with sandstone

Alternation of greengrey and red marl with intercalation of gypsiferous sandy

Dacite

Orbitolina gray limestone

Basic rocks

Gabbro

- River $\quad$ Fault $\square$ City - Drilling wells

$A-A^{\prime} \quad$ Location of geological cross section

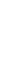


Fig. 4 Simplified stratigraphic sequence in the study area (after ELC-ELECTRO Consult 1969)

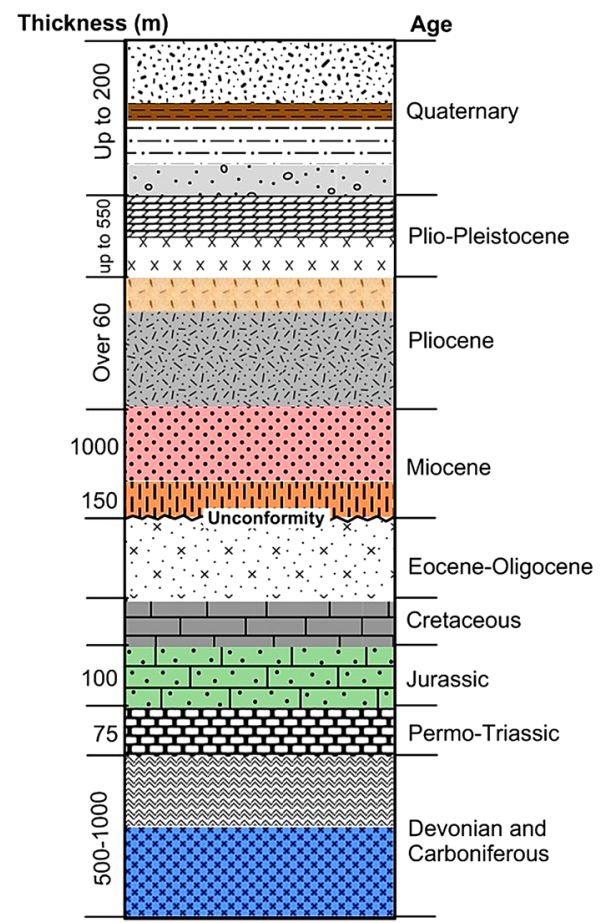

\section{Legend}

Recent deposits and terraces
Srown loam and clay

discharges and saline water during the lower discharge periods (Barzegar et al. 2016a). The Aji-Chay River deposits are composed by alluvial terraces in the central parts of the plain and divide the plain in hydrogeological terms, into two southern and northern parts (Barzegar et al. 2015). There is an unconfined aquifer, which is extended over all the plain whereas the Aji-Chay River course terraces are formed multilayered sediments that the deeper layers contained confined aquifers. Therefore, the central part of the Tabriz plain contains unconfined and confined aquifers while, close to highlands there are only unconfined aquifers (Fig. 5). Maximum thickness of the unconfined aquifer is $100 \mathrm{~m}$ and it decreases to $50 \mathrm{~m}$ toward the central part of the plain (Barzegar et al. 2015). The Aji-Chay River terraces form multilayer aquifers, but separation of unconfined aquifer from confined aquifers with respect to water quality occurs at $50-60 \mathrm{~m}$ below the ground surface. Groundwater quality above $60 \mathrm{~m}$ depth is saline, whereas from 60 to $120 \mathrm{~m}$ it is fresh water (Asghri Moghaddam 1991; Barzegar et al. $2016 \mathrm{~b}, \mathrm{c})$. The geological cross sections of the plain are shown in Fig. 6. A detailed description of the hydrogeology of the Tabriz plain is presented in works by Asghari Asghri Moghaddam (1991), Barzegar (2014), Barzegar et al. (2015, 2016a, b, c), Barzegar and Asghari Moghaddam (2016). The general direction of groundwater flow follows the topography of the area, mainly from northeast to southwest and east to west (Fig. 5).

The hydraulic parameters of the aquifers are widely variable due to the lithological and geometric variability of the deposits. Pumping test analyses showed that the values of transmissivity for the confined aquifer ranged from 820 to $2174 \mathrm{~m} / \mathrm{d}$, whilst an average transmissivity of the order of $3500 \mathrm{~m} / \mathrm{d}$ was obtained from the pumping test analyses of the unconfined aquifer (Barzegar et al. 2016c).

\section{Groundwater sampling and chemical analysis}

Totally 30 groundwater samples were collected from shallow and deep wells in July 2012. Location of the sampling points is shown in Fig. 5. The $\mathrm{pH}$ and electrical conductivity (EC) of the groundwater samples were measured in the field. The collected water samples were analyzed in the laboratory for cations $\left(\mathrm{Ca}^{2+}, \mathrm{Mg}^{2+}, \mathrm{Na}^{+}\right.$and $\left.\mathrm{K}^{+}\right)$and anions $\left(\mathrm{HCO}_{3}{ }^{-}, \mathrm{CO}_{3}{ }^{2-}, \mathrm{SO}_{4}{ }^{2-}, \mathrm{Cl}^{-}\right.$and $\left.\mathrm{NO}_{3}{ }^{-}\right)$ using the standard methods as suggested by the American Public Health Association (APHA 2005). Sodium $\left(\mathrm{Na}^{+}\right.$) and potassium $\left(\mathrm{K}^{+}\right)$were determined by flame photometer. Calcium $\left(\mathrm{Ca}^{2+}\right)$, carbonate $\left(\mathrm{CO}_{3}{ }^{2-}\right)$, bicarbonate $\left(\mathrm{HCO}_{3}{ }^{-}\right)$ and chloride $\left(\mathrm{Cl}^{-}\right)$were analyzed by volumetric methods and sulfate $\left(\mathrm{SO}_{4}{ }^{2-}\right)$ and nitrate $\left(\mathrm{NO}_{3}{ }^{-}\right)$by spectrophotometry at "Hydrogeology Laboratory of University of Tabriz". Statistical parameters of analyzed samples are shown in Table 1. EC values were used to approximate total dissolved solids (TDS) by the following equation (Lloyd and Heathcote 1985):

$\mathrm{TDS}=K_{\mathrm{e}} \cdot \mathrm{EC}$,

where TDS is expressed in $\mathrm{mg} \mathrm{L}^{-1}$ and electrical conductivity (EC) in $\mu \mathrm{S} \mathrm{cm}^{-1}$. The correlation factor varies 
Fig. 5 A schematic position of the aquifer types and location of the sampling points in the study area

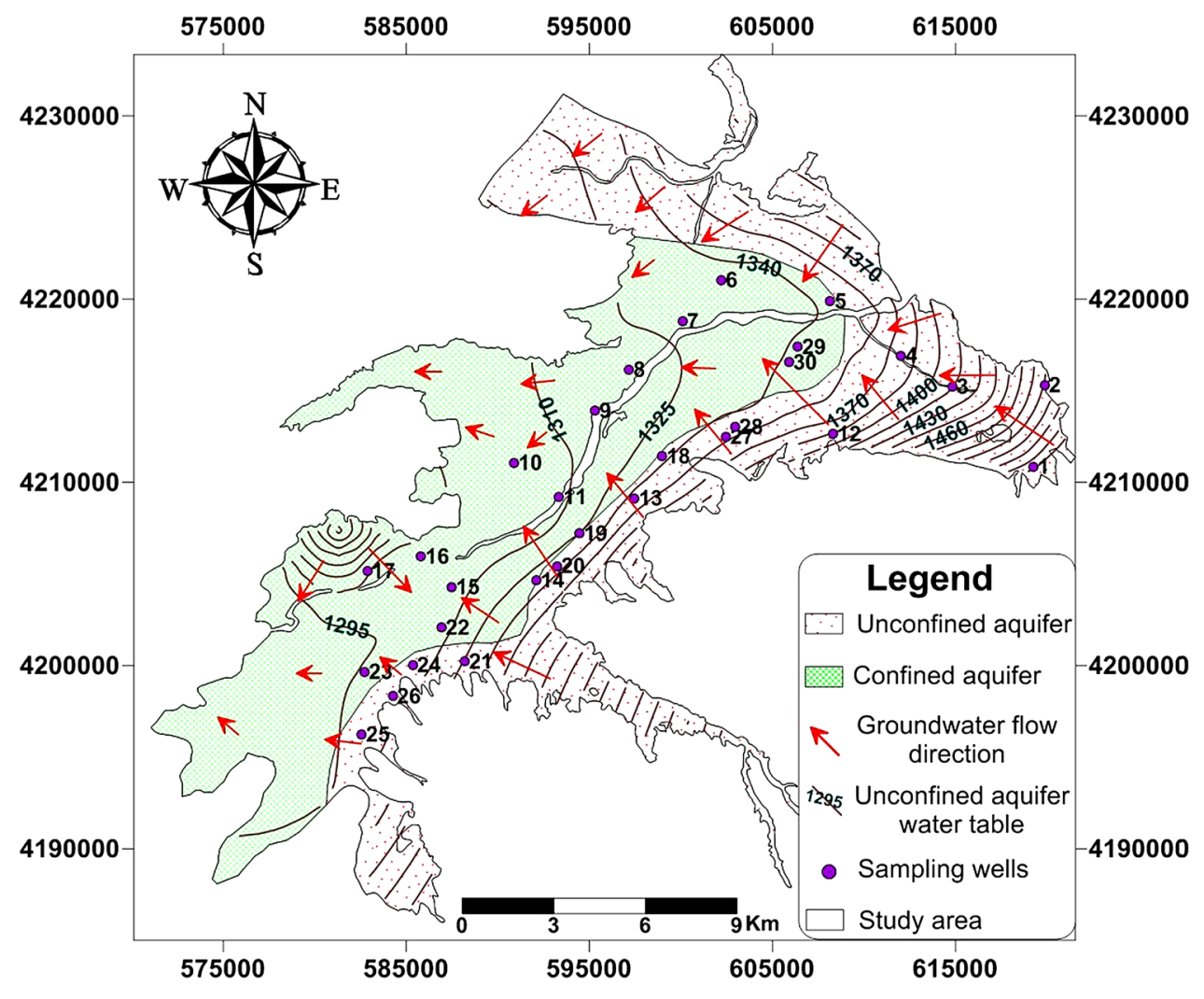

(a)

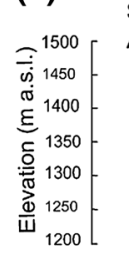

(b)

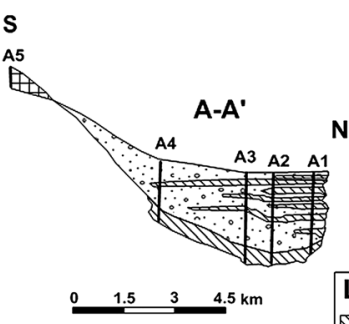

Fig. 6 Schematic cross section and $\mathrm{B}$ '-B lines (positions marked in Fig. 3) between 0.55 and 0.8 . In this study, we assumed the average value 0.65 to approximate TDS.

The accuracy of the analysis was calculated from the ion balance equation (Eq. 2).

$B=\frac{(C-A)}{(C+A)} \times 100$,

where $C$ and $A$ are the concentrations of total cations and total anions, respectively, in meq $\mathrm{L}^{-1}$, and $B$ is the percentage of ionic balance error (Domenico and Schwartz 1990). The ion balance error did not exceed $5 \%$ in any of the sample analyses.

The saturation indices of the minerals in the water were calculated by the saturation index (SI) using PHREEQC version 3.0. The SI is defined as (Parkhurst and Appelo 1999):

$\mathrm{SI}=\log _{10}\left(\frac{\mathrm{IAP}}{K_{\mathrm{sp}}}\right)$,

where IAP is the ion activity product of the dissociated chemical species in solution, $K_{\mathrm{sp}}$ is the equilibrium solubility product of the chemical involved at the sample temperature. The SI $<0$ indicates that the groundwater is undersaturated (dissolution) with respect to that particular mineral, while the SI $>0$ specifies that the groundwater being supersaturated (precipitation) with respect to the particular mineral phase and therefore incapable of dissolving more mineral phase (Barzegar et al. 2015). 
Table 1 Descriptive statistics of EC, $\mathrm{pH}$, analyzed ions and some computed minerals saturation indices for the groundwater samples

\begin{tabular}{|c|c|c|c|c|c|c|c|}
\hline & Unit & Minimum & Median & Mean & Maximum & Variance & Std. deviation \\
\hline EC & $\mu \mathrm{S} \mathrm{cm}-1$ & 693.00 & 3400.00 & 4300.00 & $12,500.00$ & $8.6 \times 10^{6}$ & 2940.00 \\
\hline $\mathrm{pH}$ & - & 7.50 & 7.90 & 7.90 & 8.40 & 0.05 & 0.23 \\
\hline $\mathrm{Ca}^{2+}$ & meq $\mathrm{L}^{-1}$ & 1.95 & 10.04 & 10.26 & 23.00 & 36.78 & 6.06 \\
\hline $\mathrm{Mg}^{2+}$ & meq $\mathrm{L}^{-1}$ & 0.96 & 6.62 & 7.89 & 24.00 & 24.31 & 4.93 \\
\hline $\mathrm{Na}^{+}$ & meq $\mathrm{L}^{-1}$ & 1.60 & 16.62 & 27.8 & 93.91 & 615.66 & 24.81 \\
\hline $\mathrm{K}^{+}$ & meq $\mathrm{L}^{-1}$ & 0.35 & 0.95 & 1.30 & 3.80 & 0.72 & 0.84 \\
\hline $\mathrm{HCO}_{3}{ }^{-}$ & meq $\mathrm{L}^{-1}$ & 3.83 & 5.75 & 6.15 & 10.87 & 3.36 & 1.83 \\
\hline $\mathrm{CO}_{3}{ }^{2-}$ & meq $\mathrm{L}^{-1}$ & 0.00 & 0.00 & 0.18 & 0.88 & 0.084 & 0.28 \\
\hline $\mathrm{Cl}^{-}$ & meq $\mathrm{L}^{-1}$ & 1.40 & 19.40 & 31.70 & 113.00 & 876.00 & 29.59 \\
\hline $\mathrm{SO}_{4}^{2-}$ & meq $\mathrm{L}^{-1}$ & 1.29 & 7.18 & 8.12 & 17.68 & 24.19 & 4.91 \\
\hline $\mathrm{NO}_{3}{ }^{-}$ & meq $\mathrm{L}^{-1}$ & 0.01 & 0.68 & 0.89 & 3.93 & 95.00 & 0.97 \\
\hline $\mathrm{SI}_{\text {Calcite }}$ & - & 0.10 & 0.98 & 0.91 & 1.25 & 0.10 & 0.32 \\
\hline $\mathrm{SI}_{\text {Dolomite }}$ & - & 1.13 & 2.21 & 2.09 & 2.91 & 0.16 & 0.41 \\
\hline $\mathrm{SI}_{\text {Gypsum }}$ & - & -2.39 & -0.109 & -1.04 & 0.86 & 0.42 & 0.65 \\
\hline $\mathrm{SI}_{\text {Anhydrite }}$ & - & -2.61 & -1.30 & -1.35 & -0.70 & 0.17 & 0.42 \\
\hline $\mathrm{SI}_{\text {Halite }}$ & - & -7.32 & -5.25 & -5.15 & -3.13 & 0.71 & 0.84 \\
\hline
\end{tabular}

Descriptive statistics of computed SIs of some minerals, including calcite, dolomite, gypsum, anhydrite and halite are listed in Table 1.

\section{Results and discussion}

\section{Hydrochemical facies}

Chadha's classification (Chadha 1999) was proposed to identify the groundwater type. As shown in Fig. 7, the main hydrochemical facies in the study area are $\mathrm{Na}-\mathrm{Cl}$ and mixed $\mathrm{Ca}-\mathrm{Mg}-\mathrm{Cl}$. Only one of data points fall in field 5 $\left(\mathrm{Ca}-\mathrm{Mg}-\mathrm{HCO}_{3}\right.$ water type) which indicates alkaline earths

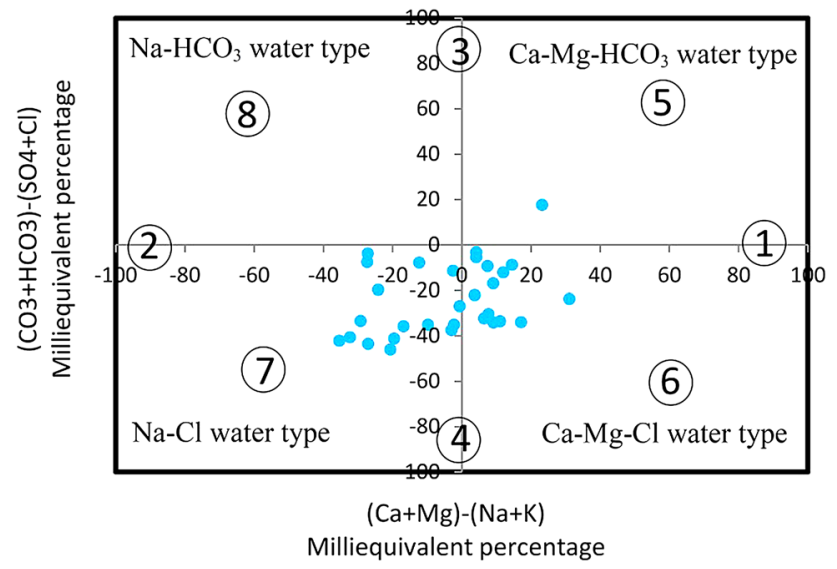

Fig. 7 Chadha's diagram showing chemical characteristic of groundwater in the Tabriz plain aquifer and weak acidic anions exceed both alkali metals and strong acidic anions, respectively. Such water has temporary hardness. Thirteen data points fall in the field $6(\mathrm{Ca}-$ $\mathrm{Mg}-\mathrm{Cl}$ water type) which represent alkaline earths that exceed alkali metals and strong acidic anions exceed weak acidic anions. Such water has permanent hardness and does not deposit residual sodium carbonate in irrigation use. Sixteen data points fall in field $7(\mathrm{Na}-\mathrm{Cl}$ water type) which represent alkali metals exceed alkaline earths and strong acidic anions exceed weak acidic anions. Such water generally creates salinity problems both in irrigation and drinking uses (Sutharsiny et al. 2012).

\section{Spatial variability of groundwater quality parameters}

The EC values of the groundwater samples range from $693 \mu \mathrm{S} \mathrm{cm}^{-1}$ in the close the northern slopes of the Sahand Mountains to $12,500 \mu \mathrm{S} \mathrm{cm}{ }^{-1}$ in the southwest region of the aquifer. Low EC (sample 1) is located in the recharge areas originating from coarse-grained alluvial fans, while individual elevated EC values (e.g., sample 7) should have probably variable origins, such as the low depth of water table and subsequent increased evaporation, the elevated salinity of Aji-Chay River (average $\mathrm{EC}=9500 \mu \mathrm{S} \mathrm{cm}{ }^{-1}$ ) which is hydraulically connected to groundwater (Barzegar et al. 2016a) and, the excessive use of salts from industrial tanning activities. Spatial distribution of the EC is shown in Fig. 8a. Generally, EC values increase from recharge areas in eastern and southern edges towards discharge areas in west and southwest. However, anomalies can be observed 

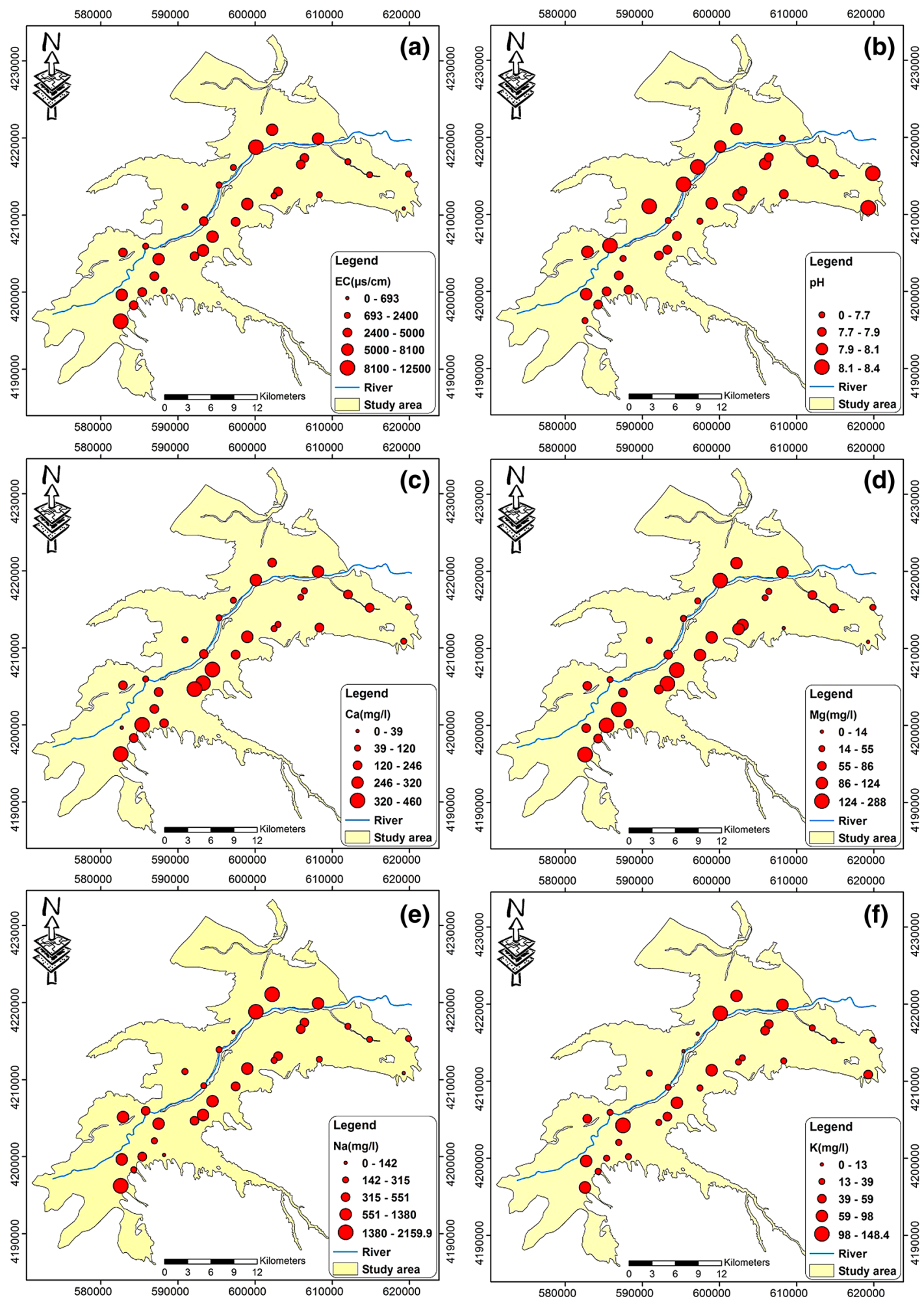

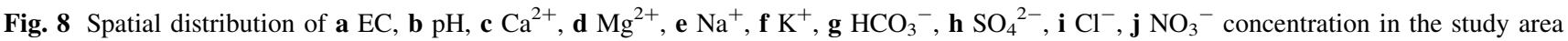

in this trend due to geological formations, groundwater extraction amount, size and type of sediments, depth of groundwater and, interactions between aquifer systems in the area. It should be noted that the depth of sampling wells can affect the EC values, because the groundwater salinity of the confined and unconfined aquifers varies significantly. The critical threshold of $1500 \mu \mathrm{S} \mathrm{cm}{ }^{-1}$ (World Health Organization (WHO) 2011) for drinking water 
purposes is exceeded in all samples except three of them (1, 8 and 9); a fact which denotes a significant environmental pressures of salinity.

The $\mathrm{pH}$ of samples varies between 7.5 and 8.4. Generally, samples which are in the range of $\mathrm{pH}$ between 6 and 9 are in their natural state (Stumm and Morgan 1996). This is due to the natural waters generally containing dissolved carbon dioxide and hydrogen ions and carbonates (Mokhtar et al. 2009) which forms a buffer system (Eq. 4 and 5).

$$
\begin{aligned}
& \mathrm{H}_{2} \mathrm{O}+\mathrm{CO}_{2} \rightarrow \mathrm{H}_{2} \mathrm{CO}_{3} \\
& \mathrm{H}_{2} \mathrm{CO}_{3} \rightarrow 2 \mathrm{H}^{+}+\mathrm{CO}_{3}^{2-} .
\end{aligned}
$$

The distribution map of $\mathrm{pH}$ values (Fig. 8b) shows that $\mathrm{pH}$ is high in the eastern part of the study area due to high bicarbonate levels in groundwater, while $\mathrm{pH}$ levels are decreased towards the central parts due to low levels of bicarbonate and high salinity. As well as, groundwater $\mathrm{pH}$ increases with water residual time because the interaction of water-rock will consume $\mathrm{H}^{+}$(Hinkle and Polette 1999). Therefore, $\mathrm{pH}$ is increased in the central parts of plain due to low hydraulic gradient and high water residual time.

The calcium content of the samples varies between 39 and $460 \mathrm{mg} \mathrm{L}^{-1}$. According to World Health Organization (WHO) (2011) standards, its permissible range in drinking water is $75 \mathrm{mg} \mathrm{L}^{-1}$. Calcium in the groundwater can originate from Miocene and Pliocene formations, e.g. limestone, sandstone, conglomerate, gypsum in the study area. Concentration of calcium against sodium is low, revealing a lack of soluble calcium minerals, as calcium of groundwater is replaced by sodium through ion exchange reaction (Sharma and Rao 1997).

Sodium ion appears an elevated concentrations; the amount of $\mathrm{Na}^{+}$ion increases from recharge to discharge areas, likewise $\mathrm{Cl}^{-}$denoting their relationship. The origin of $\mathrm{Na}^{+}$in groundwater of the study area may be attributed to the dissolution of sodium-bearing minerals (especially halite), plagioclase weathering (Eq. 6), ion exchange reactions (replacing the calcium and magnesium with sodium in clays), irrigation water return flow and municipal and/or industrial wastewater.

$$
\begin{aligned}
& 2 \mathrm{NaAlSi}_{3} \mathrm{O}_{8}+2 \mathrm{CO}_{2}+11 \mathrm{H}_{2} \mathrm{O} \\
& \quad \rightarrow 2 \mathrm{Na}^{+}+2 \mathrm{HCO}_{3}^{-}+4 \mathrm{H}_{4} \mathrm{SiO}_{4(\mathrm{aq})}+\mathrm{Al}_{2} \mathrm{Si}_{2} \mathrm{O}_{5}(\mathrm{OH}) .
\end{aligned}
$$

The potassium concentration is variable ranging between 13.8 and $148.5 \mathrm{mg} \mathrm{L}^{-1}$ (Fig. 8f), while the optimal level of potassium in drinking water is $12 \mathrm{mg}$ $\mathrm{L}^{-1}$ which indicates potassium is excessive in groundwater (World Health Organization (WHO) 2011). Potassium in the groundwater of the study area can originate from weathering K-bearing minerals such as feldspars (Eq. 7), industrial activities and agricultural fertilizers potash which is used by farmers. Additionally, irrigation water return flow may increase overall $\mathrm{K}$ concentrations,

$$
\begin{aligned}
& 2 \mathrm{KAlSi}_{3} \mathrm{O}_{8}+2 \mathrm{CO}_{2}+11 \mathrm{H}_{2} \mathrm{O} \\
& \quad \rightarrow 2 \mathrm{~K}^{+}+2 \mathrm{HCO}_{3}^{-}+4 \mathrm{H}_{4} \mathrm{SiO}_{4(\mathrm{aq})}+\mathrm{Al}_{2} \mathrm{Si}_{2} \mathrm{O}_{5}(\mathrm{OH})_{4}
\end{aligned}
$$

Spatial distribution of bicarbonate ion is shown in Fig. 8g. Bicarbonate concentrations range between 234.1 and $663.1 \mathrm{mg} \mathrm{L}^{-1}$. Elevated $\mathrm{Ca}$ concentrations may be attributed to dissolution of limestones, Ca-rich feldspars, and potentially due to biodegradation or organic matter in upper soil horizons.

Sulfate concentrations vary between 62.2 and $847.6 \mathrm{mg} \mathrm{L}^{-1}$ (Fig. 8h). Sulfate concentration greater than $50 \mathrm{mg} \mathrm{L}^{-1}$ causes a bitter taste in water and in higher concentration of $400 \mathrm{mg} \mathrm{L}^{-1}$ with calcium and magnesium can cause frailty in the body (Shankar et al. 2008). Anomalies of sulfate spatial shows compliance with calcium and magnesium distribution maps which indicates these ions originate from dissolution of Miocene and Pliocene formations which contain gypsum and anhydrite. The concentration of sulfate shows a high anomaly in Tabriz city which is affected by contamination from municipal and industrial wastewater. Also, irrigation water return flow can be another source of the $\mathrm{SO}_{4}{ }^{2-}$ in the groundwater of the study area.

Chloride concentrations range between 49.7 and $2041.2 \mathrm{mg} \mathrm{L}^{-1}$ in the groundwater of the aquifers (Fig. 8i). According to World Health Organization (WHO) (2011), concentration of chloride should not exceed $250 \mathrm{mg} \mathrm{L}^{-1}$. The origin of chloride in groundwater of the study area can originate from evaporative deposits of the Miocene formations, contamination from municipal waste and urban waste and irrigation water return flow. This statement can be confirmed with moderate-to-high correlations between $\mathrm{Cl}^{-}$and $\mathrm{Na}^{+}(r=0.965), \mathrm{Cl}^{-}$and $\mathrm{K}^{+}$ $(r=0.843), \mathrm{Cl}^{-}$and $\mathrm{SO}_{4}{ }^{2-}(r=0.617)$. The chloride increase in the plain groundwater is justified by evaporative conditions due to shallow water level, fine-grained sediments and low hydraulic gradient and thus more groundwater residual time and more dissolution.

Nitrate concentrations vary between 4 and $243.7 \mathrm{mg} \mathrm{L}^{-1}$ with an average concentration of $55.6 \mathrm{mg} \mathrm{L}^{-1}$ (Fig. 8j). Many parameters such as the amount of fertilizer used, surface water quality, land use type, depth of groundwater level, land drainage by the river and sediment type have resulted in variations of nitrate concentrations in different parts of the plain (Barzegar 2014). The lowest nitrate concentration is obtained from the northwest of the plain (sample 16) because of low agricultural activity, confined aquifers in these areas and fine-grained sediments in comparison with other parts of 
the area. The highest nitrate concentration (sample 29) is in the west of Tabriz city, which is attributed to urban and domestic sewages and dense farming in this area (Barzegar 2014). Nitrate concentration is much higher in the southern part of Aji-Chay River; it would be due to intensive agricultural activity, industrial concentration, type of aquifer and shallow groundwater. The presence of high nitrate concentration in the drinking water increases the incidence of gastric cancer and other potential hazards to infants and pregnant women (Nagireddi Srinivasa Rao 2006).

Barzegar et al. (2016b) studied the intrinsic vulnerability of Tabriz plain aquifer using the DRASTIC method. They indicated that the least vulnerable area was located in the west where the aquifer system is confined, while the most vulnerable areas were located in the east and south where the aquifer is unconfined and the recharge is high. The vulnerability map obtained an $R^{2}$ of 0.83 between DRASTIC index and $\mathrm{NO}_{3}{ }^{-}$concentrations (Barzegar 2014). The DRASTIC vulnerability map is shown in Fig. 9. The existence of a confining clay layer in the western part of the plains provides protection, reducing the risk of contamination. As shown in Fig. 9, the nitrate concentrations are high in vulnerable area and low in less vulnerable area. This indicates that there must be a special consideration in management of groundwater in the study area.

\section{Identification of the hydrochemical processes}

The scatter plots of different ions were analyzed to identify the interrelationships between the ions and possible chemical reactions which may occur in the Tabriz plain. Major ion concentrations as a function of TDS values were plotted to determine the contributing ions to groundwater

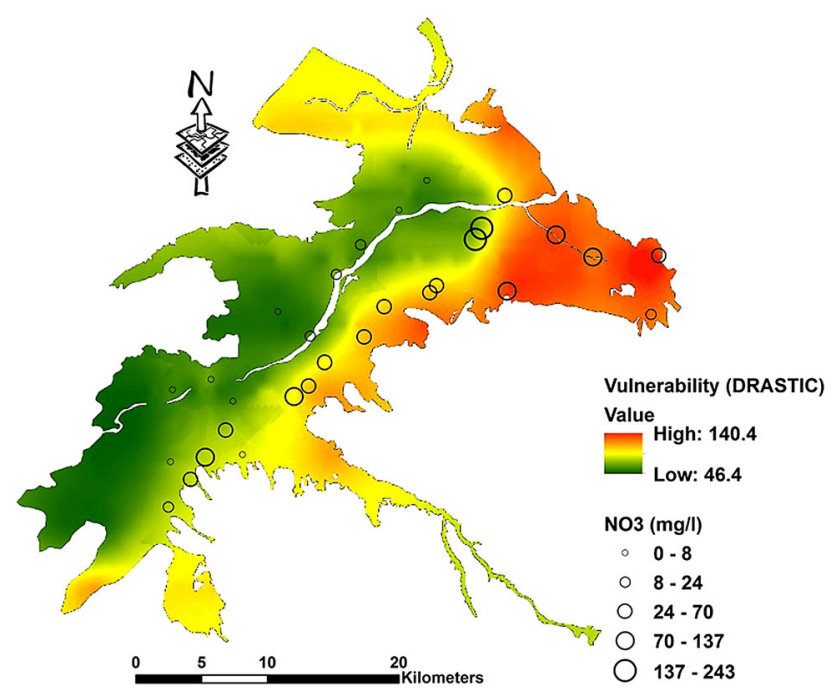

Fig. 9 DRASTIC vulnerability map of the study area with $\mathrm{NO}_{3}{ }^{-}$ concentrations mineralization. Figure 10 shows that $\mathrm{Na}^{+}$and $\mathrm{Cl}^{-}$are strongly correlated with TDS with an $R^{2}$ of 0.9374 and 0.9739 , respectively, which represent that these ions are the most effective in the mineralization and salinization of the groundwater of the study area. As well as, cross-plot of $\mathrm{K}^{+}$ with TDS (Fig. 10d) shows a good correlation with an $\mathrm{R}^{2}$ of 0.7254 , indicating that potassium contributes, with both $\mathrm{Na}^{+}$and $\mathrm{Cl}^{-}$, in groundwater mineralization.

As mentioned previously, dissolution of minerals such as gypsum $\left(\mathrm{CaSO}_{4} \cdot 2 \mathrm{H}_{2} \mathrm{O}\right)$, anhydrite $\left(\mathrm{CaSO}_{4}\right)$ and halite $(\mathrm{NaCl})$ occurs frequently across the study area. The results of the computed SI values for these mineral phases show that groundwater is significantly undersaturated with respect to halite $(-7.32 \leq \mathrm{SI} \leq-3.13)$ and, to a lesser extent, with respect to anhydrite $(-2.61 \leq \mathrm{SI} \leq-0.7)$ and gypsum $(-2.39 \leq \mathrm{SI} \leq 0.86)$, indicating that these minerals can dissolve into the groundwater of the plain. Some groundwater samples have elevated $\mathrm{Ca}^{2+}$ and $\mathrm{Mg}^{2+}$ concentrations relative to $\mathrm{HCO}_{3}{ }^{-}$which are balanced in charge by $\mathrm{SO}_{4}{ }^{2-}$. These sulfate-rich waters probably derive from dissolution of gypsum and/or anhydrite. The well-defined relationship in the plot of $\mathrm{Ca}^{2+}$ versus $\mathrm{SO}_{4}{ }^{2-}$ (Fig. 12a) confirms this deduction (Barth 2000). Also, it can be understood by the parabolic trend observed in the correlation of the negative saturation indices, with regard to the gypsum and anhydrite minerals, versus the sum of calcium and sulfate ions (Fig. 11a, b) resulting from the $\mathrm{CaSO}_{4}$ dissolution (Hamed et al. 2011). The plot of $\mathrm{Ca}^{2+}$ versus $\mathrm{SO}_{4}{ }^{2-}$ can be evidence of the predominance of the cation exchange (Tarki et al. 2011). As shown in Fig. 11a, the excess of $\mathrm{Ca}^{2+}$ in groundwater samples indicating that $\mathrm{Ca}^{2+}$ releases into water to compensate the adsorption of $\mathrm{Na}^{+}$while samples exhibiting an excess of $\mathrm{SO}_{4}{ }^{2-}$ reflects a probably oxidizing environment of the Tabriz plain. Barzegar et al. (2015) indicated the oxidizing environment of the unconfined aquifer of the Tabriz plain by measuring of Eh between 234 and $284 \mathrm{mv}$. The computed SI values show that groundwater is supersaturated with respect to calcite $(0.1 \leq \mathrm{SI} \leq 1.25)$ and dolomite $(1.13 \leq \mathrm{SI} \leq$ 2.91 ), indicating that these minerals precipitate in groundwater. This condition brings solution to equilibrium with respect to these carbonates and subsequently transported into a different environment where a higher $\mathrm{pH}$ or an apparent condition caused by the failure of the measured $\mathrm{pH}$ to accurately represent the actual equilibrium $\mathrm{pH}$ of the water in the aquifer (Kortatsi 2007; Christian et al. 2014).

The plot of $\mathrm{Ca}^{2+}+\mathrm{Mg}^{2+}$ versus $\mathrm{Na}^{+}$(Fig. 12b) was used to identify the ion exchange process. This plot shows that data points fall in the both sides of the 1:1 line indicating that ion exchange as well as some reverse ion exchange is taking place in the study area. Reverse ion exchange normally occurs in the presence of clays, As previously mentioned aquifer materials contain clays, 
(a)

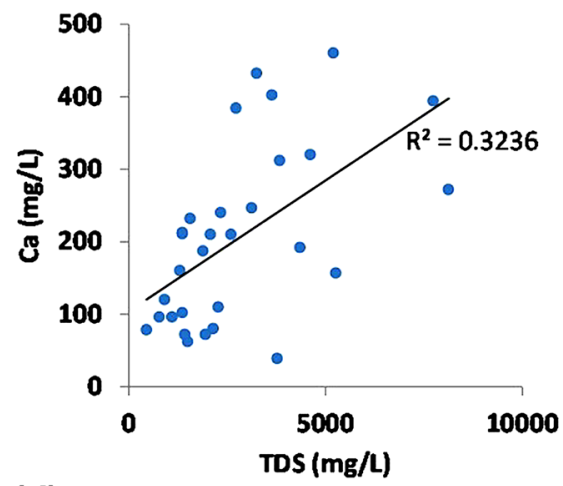

(d)

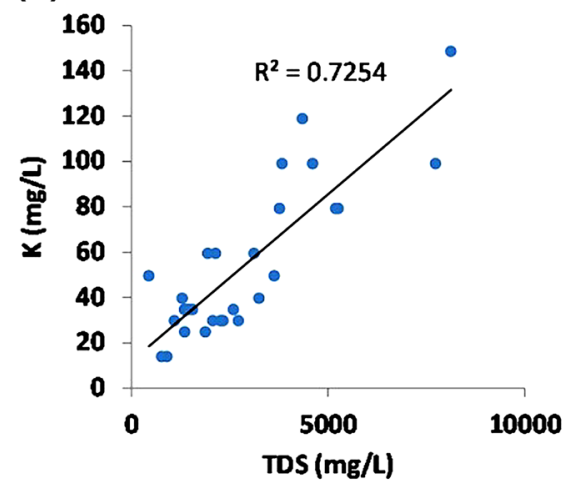

(b)

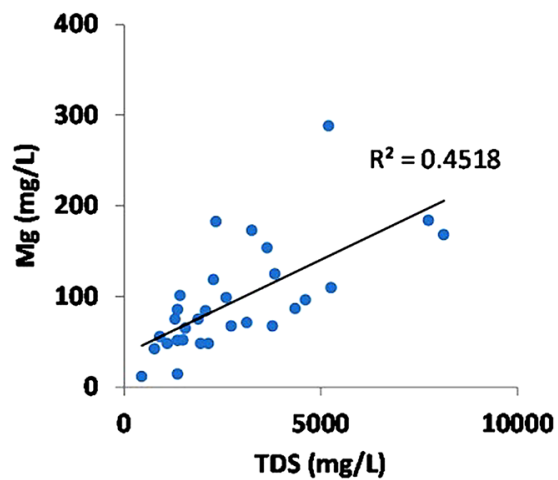

(e)

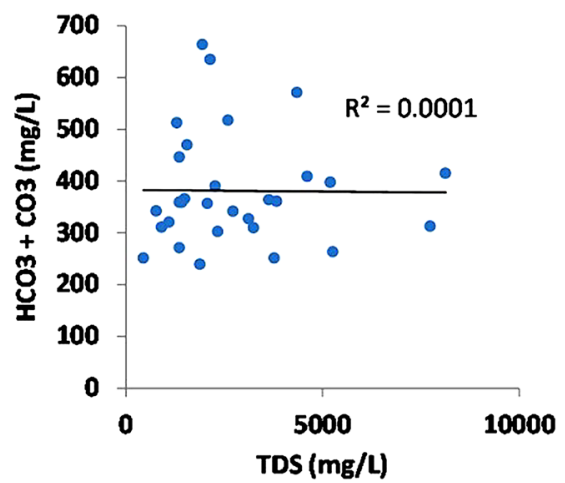

(c)

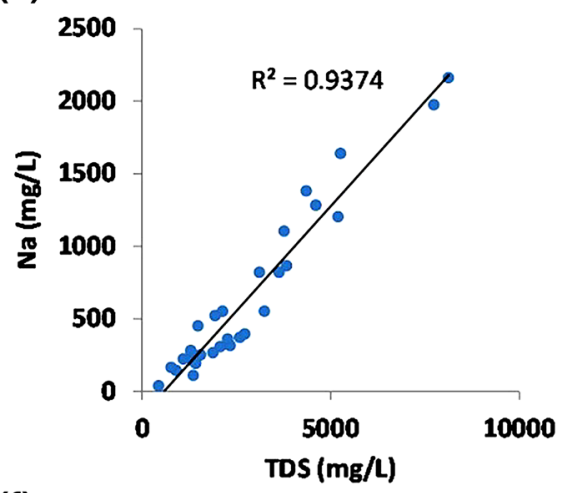

(f)

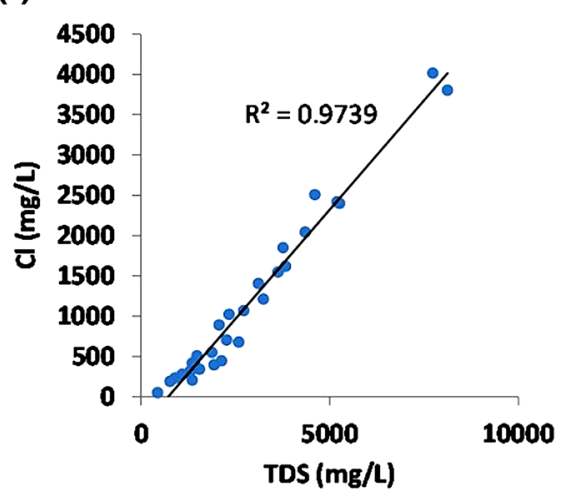

(g)

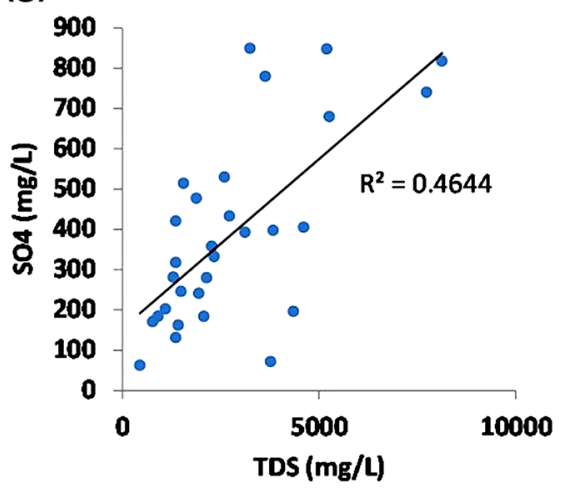

Fig. 10 Plots of major ions versus TDS

where the $\mathrm{Na}^{+}$is removed from the system with the release of $\mathrm{Ca}^{2+}+\mathrm{Mg}^{2+}$.

The plot of $\mathrm{Na}^{+} / \mathrm{Cl}^{-}$versus EC was used to characterize the impact of the evaporation on the groundwater chemistry. This plot would give a horizontal line, which would then be an effective indicator of the concentration by evaporation, evapotranspiration and halite dissolution. Theoretically, the $\mathrm{Na}^{+} / \mathrm{Cl}^{-}$ratio approximately equal to one is attributed to halite dissolution, whereas a ratio greater than one is typically indicative for $\mathrm{Na}^{+}$release due to silicate weathering (Meybeck 1987). Generally the molar ratio of $\mathrm{Na}^{+} / \mathrm{Cl}^{-}$for groundwater samples ranges from 0.38 to 2.1 (Fig. 12b). Most of the samples have $\mathrm{Na}^{+}$/
$\mathrm{Cl}^{-}$molar ratio below one, indicating that halite dissolution was the major process. Scatter plot of EC versus $\mathrm{Na}^{+} /$ $\mathrm{Cl}^{-}$shows an inclined trend line, which indicates that evaporation may not be the major geochemical process controlling the chemistry of the groundwater. As well as, halite dissolution indicates by the well-defined relationship in the correlation of the negative saturation indices versus the sum of ions resulting from the $\mathrm{NaCl}$ dissolution (Fig. 11c).

The impact of silicate weathering on groundwater system can be found by plot of $\mathrm{Na}^{+}+\mathrm{K}^{+}$versus total cations (TC). As shown in Fig. 11d, most of the data points are plotted above the $\mathrm{Na}^{+}+\mathrm{K}^{+}=0.5 \mathrm{TC}$. This indicates the 
Fig. 11 Plots of

a $\left(\mathrm{Ca}^{2+}+\mathrm{SO}_{4}{ }^{2-}\right)$ versus SI of gypsum, b $\left(\mathrm{Ca}^{2+}+\mathrm{SO}_{4}{ }^{2-}\right)$ versus $\mathrm{SI}$ of anhydrite and c $\left(\mathrm{Na}^{+}+\mathrm{Cl}^{-}\right)$versus SI of halite

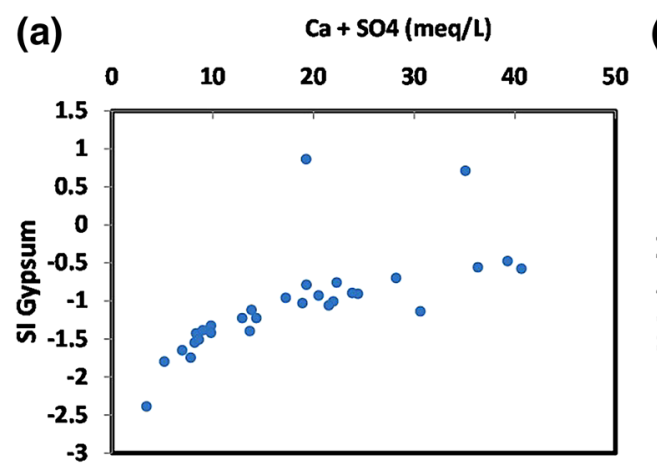

(b) $\mathrm{Ca}+504(\mathrm{meq} / \mathrm{L})$
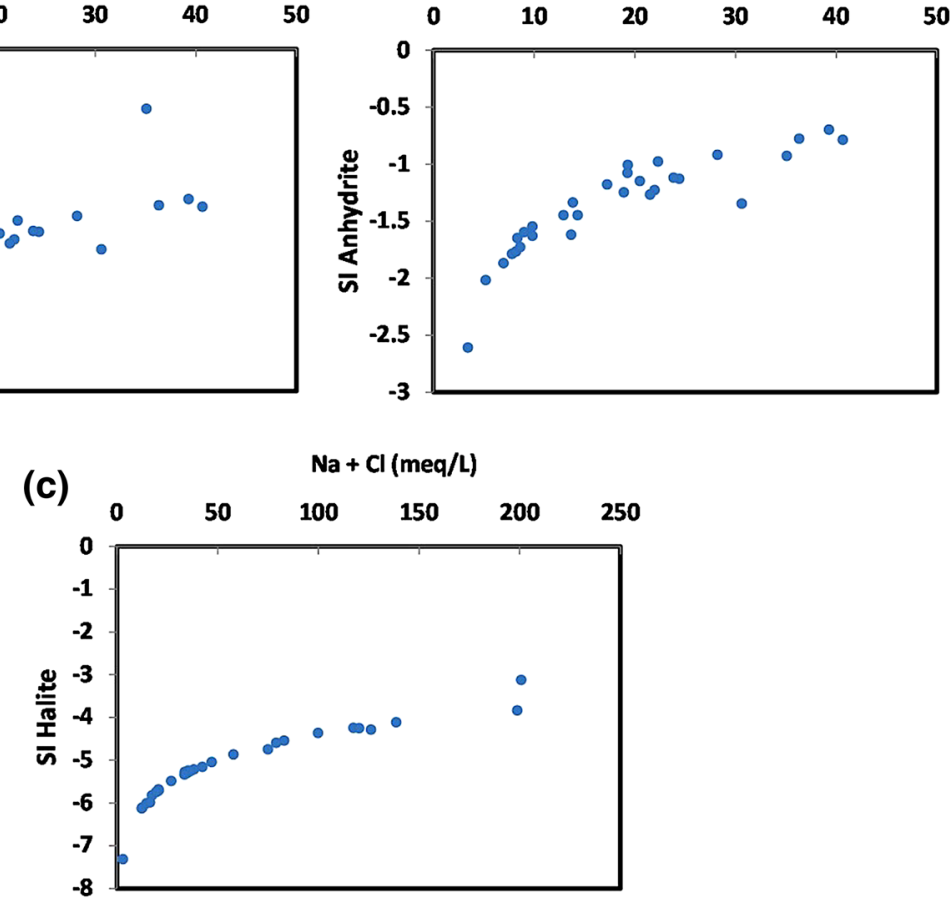

Fig. 12 Plots of $\mathrm{a} \mathrm{SO}_{4}{ }^{2-}$ versus $\mathrm{Ca}^{2+}, \mathbf{b ~ N a}{ }^{+}$versus $\mathrm{Ca}^{2+}+\mathrm{Mg}^{2+}$, c EC versus $\mathrm{Na}^{+} / \mathrm{Cl}^{-}$and $\mathbf{d}$ TC versus $\mathrm{Na}^{+}+\mathrm{K}^{+}$

(a)

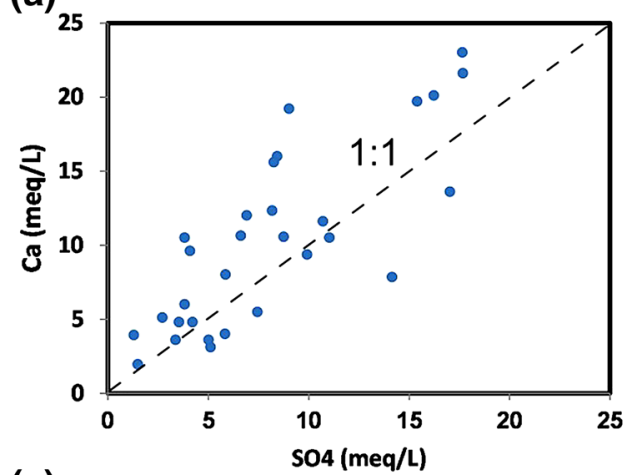

(c)

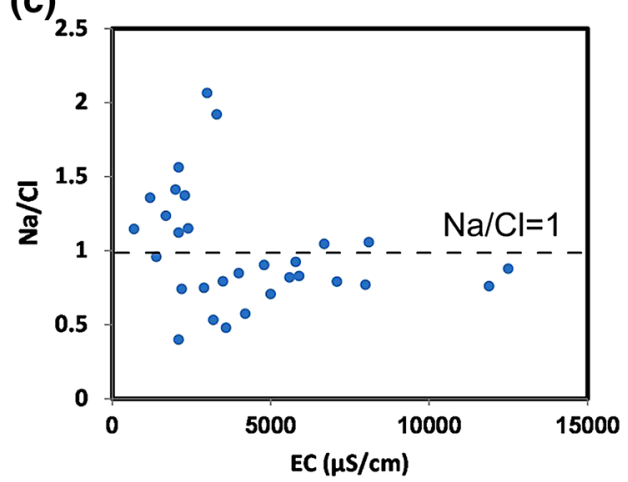

(b)

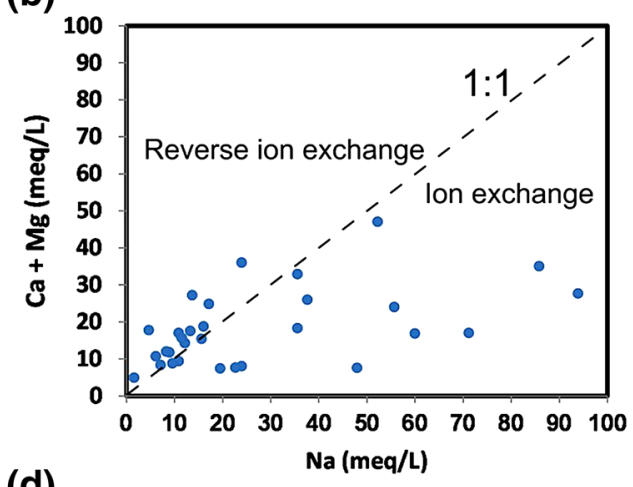

(d)

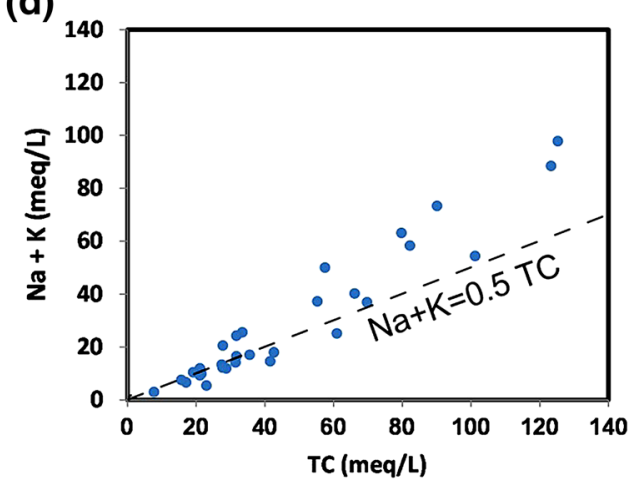

involvement of silicate weathering in the groundwater system, which contributes $\mathrm{Na}^{+}$and $\mathrm{K}^{+}$to the groundwater (Stallard and Edmond 1983; Rajmohan and Elango 2004; Senthilkumar and Elango 2013).
As previously mentioned, agriculture and industry are the main human activities in the study area. Therefore, the chemistry of the groundwater can be influenced by anthropogenic activities. Gillardet et al. (1999) suggested 


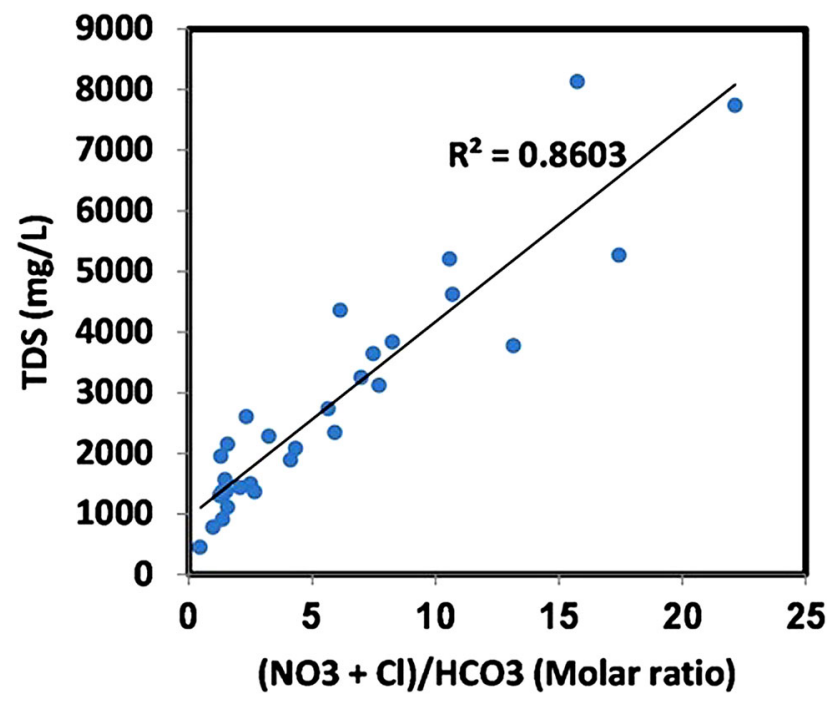

Fig. 13 Plot of TDS values versus $\left(\mathrm{NO}_{3}{ }^{-}+\mathrm{Cl}^{-}\right) / \mathrm{HCO}_{3}{ }^{-}$molar ratios

that variation in TDS of groundwater may be attributed to land use and as a result of contamination. It is well known that in rural areas $\mathrm{NO}_{3}{ }^{-}, \mathrm{SO}_{4}{ }^{2-}, \mathrm{Na}^{+}$and $\mathrm{Cl}^{-}$ions are mostly derived from agricultural fertilizers, animal waste, and municipal and industrial sewage (Jalali 2009; Nagaraju et al. 2014). Han and Liu (2004) and Jalali (2009) suggested that the high correlation between TDS and $\left(\mathrm{NO}_{3}{ }^{-}+\mathrm{Cl}^{-}\right) / \mathrm{HCO}_{3}{ }^{-}$molar ratios reveals the influence of anthropogenic activities on water chemistry. As shown in Fig. 13, there is a positive correlation with an $R^{2}$ of 0.8603 between TDS values and $\left(\mathrm{NO}_{3}{ }^{-}+\mathrm{Cl}^{-}\right) / \mathrm{HCO}_{3}{ }^{-}$ molar ratios which indicates that human activities affect the chemistry of the groundwater.

Gibbs (1970) plots of log TDS against $\mathrm{Na}^{+} /\left(\mathrm{Na}^{+}+\right.$ $\left.\mathrm{Ca}^{2+}\right)$ and $\mathrm{Cl}^{-} /\left(\mathrm{Cl}^{-}+\mathrm{HCO}_{3}{ }^{-}\right)$were used to identify the groundwater interaction, with precipitation (rainfall), rock and evaporation, as the mechanisms controlling the groundwater chemistry. The ratios $\mathrm{Na}^{+} /\left(\mathrm{Na}^{+}+\mathrm{Ca}^{2+}\right)$ of as well as anions $\mathrm{Cl}^{-} /\left(\mathrm{Cl}^{-}+\mathrm{HCO}_{3}{ }^{-}\right)$are plotted from the rock domain towards the evaporation domain (Fig. 14a, b), which reflect that rock-water interaction, as a major source of dissolved ions, and evaporation occur in the groundwater system. Some of the plotted data points in the evaporation domain show a dense clustering. As suggested by $\mathrm{Li}$ et al. (2013), the dense clustering of points in the evaporation domain can be an indication of anthropogenic activities.

\section{Conclusions}

Electrical conductivity (EC) values of the groundwater are highly variable. The elevated EC values should be chiefly attributed to irrigation water return flow. However, additional causes such as the induced evaporation due to low depth of water table, the hydraulic connection with the Aji-Chay River and, the dissolution of evaporitic formations act as supplementary sources of salinization and contribute the overall outcome. Mixed $\mathrm{Ca}-\mathrm{Mg}-\mathrm{Cl}$ and $\mathrm{Na}-\mathrm{Cl}$ type of groundwater is predominant in the study area. The concentrations of some major ions in groundwater are above the permissible limit for drinking and domestic purpose except for a few locations. $\mathrm{Na}^{+}$ and $\mathrm{Cl}^{-}$are strongly correlated with TDS with an $R^{2}$ of 0.9374 and 0.9739 , respectively, which indicates that these ions are the most effective in the mineralization and salinization of the groundwater of the study area. Scatter plots show that rockwater interaction, evaporation, cation exchange and anthropogenic activities are predominant processes that take place in the aquifer. A strong correlation with $R^{2}=0.8603$ between TDS values and $\left(\mathrm{NO}_{3}{ }^{-}+\mathrm{Cl}^{-}\right) / \mathrm{HCO}_{3}{ }^{-}$molar ratios indicates the impact of human activities on groundwater chemistry. The results of saturation index (SI) computation and different scatter plots show that dissolution of gypsum, (a)

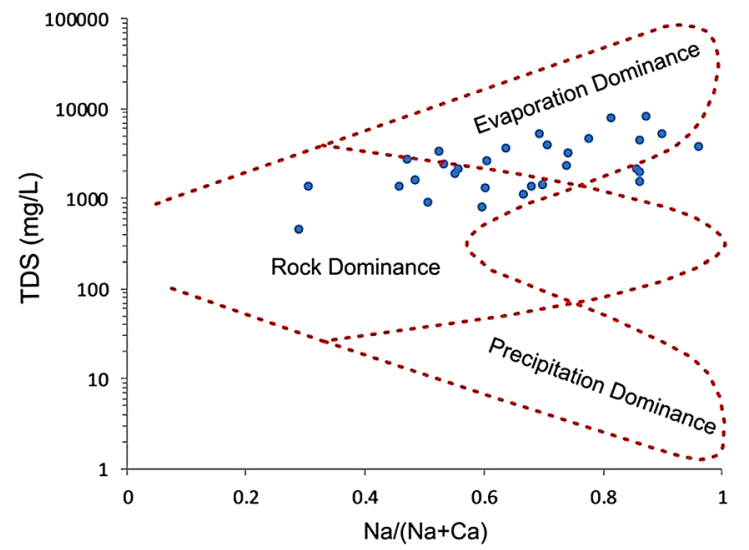

(b)

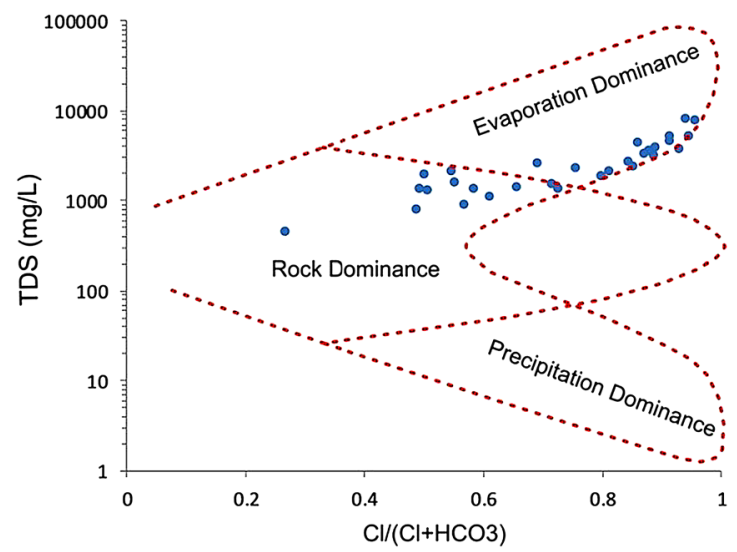

Fig. 14 Plots of a log TDS versus $\mathrm{Na}^{+} /\left(\mathrm{Na}^{+}+\mathrm{Ca}^{2+}\right)$ and $\mathbf{b} \log$ TDS versus $\mathrm{Cl}^{-} /\left(\mathrm{Cl}^{-}+\mathrm{HCO}_{3}^{-}\right.$) (after Gibbs 1970) 
anhydrite, halite and silicate minerals occurred frequently across the study area, while groundwater is supersaturated with respect to calcite and dolomite; therefore, these minerals precipitate in the groundwater.

Acknowledgements The authors are thankful to Mr. Masoud Orouji and Mrs. Naeimeh Kazemian for their help in analyzing of the water samples and Mr. Mortaza Najib for his kind help in the collection of some data.

Open Access This article is distributed under the terms of the Creative Commons Attribution 4.0 International License (http:// creativecommons.org/licenses/by/4.0/), which permits unrestricted use, distribution, and reproduction in any medium, provided you give appropriate credit to the original author(s) and the source, provide a link to the Creative Commons license, and indicate if changes were made.

\section{References}

Aghazadeh N, Asghari Moghaddam A (2010) Assessment of groundwater quality and its suitability for drinking and agricultural uses in the Oshnavieh area, northwest of Iran. J Environ Prot 1:30-40

APHA (2005) Standard methods for the examination of water and wastewater. American Public Health Association, Washington

Arumugam K, Elangovan K (2009) Hydrochemical characteristics and groundwater quality assessment in Tirupur region, Coimbatore district, Tamil Nadu, India. Environ Geol 58:1509-1520

Asghri Moghaddam A (1991) The hydrogeology of the Tabriz area, Iran. Ph.D. thesis, Department of Geological Sciences, University College London

Asghri Moghaddam A, Allaf Najib M (2006) Hydrogeologic characteristics of the alluvial tuff aquifer of northern Sahand Mountain slopes, Tabriz, Iran. Hydrogeol J 14(7):1319-1329

Barth SR (2000) Stable isotope geochemistry of sediment-hosted groundwater from a Late Paleozoic-Early Mesozoic section in central Europe. J Hydrol 235:72-87

Barzegar R (2014) Investigation of quantitative and qualitative of Tabriz plain aquifer groundwater resources. MSc thesis, Department of Natural sciences, University of Tabriz

Barzegar R, Asghari Moghaddam A (2016) Combining the advantages of neural networks using the concept of committee machine in the groundwater salinity prediction. Modeling Earth Syst Environ. doi:10.1007/s40808-015-0072-8

Barzegar R, Asghari Moghaddam A, Kazemian N (2015) Assessment of heavy metals concentrations with emphasis on arsenic in the Tabriz plain aquifers, Iran. Environ Earth Sci 74:297-313

Barzegar R, Adamowski J, Asghari Moghaddam A (2016a) Application of wavelet-artificial intelligence hybrid models for water quality prediction: a case study in Aji-Chay River, Iran. Stoch Environ Res Risk Assess. doi:10.1007/s00477-016-1213-y

Barzegar R, Asghari Moghaddam A, Baghban H (2016b) A supervised committee machine artificial intelligent for improving DRASTIC method to assess groundwater contamination risk: a case study from Tabriz plain aquifer, Iran. Stoch Environ Res Risk Assess. doi:10.1007/s00477-015-1088-3

Barzegar R, Asghari Moghaddam A, Najib M, Kazemian N, Adamowski J (2016c) Characterization of hydrogeologic properties of the Tabriz plain multi-layer aquifer system. Arab J Geo, NW Iran. doi:10.1007/s12517-015-2229-1
Barzegar R, Asghari Moghaddam A, Tziritis E (2016d) Assessing the hydrogeochemistry and waterquality of the Aji-Chay River, northwest of Iran. Environ Earth Sci 75:1486

Barzegar R, Asghari Moghaddam A, Adamowski J, Ozga-Zielinski B (2017) Multi-step water quality forecasting using a boosting ensemble multi-wavelet extreme learning machine model. Stoch Environ Res Risk Assess. doi:10.1007/s00477-017-1394-z

Belkhiri L, Mouni L, Boudoukha A (2012) Geochemical evolution of groundwater in an alluvial aquifer: case of El Eulma aquifer, East Algeria. J African Earth Sci 66:46-55

Cartwright I, Weaver T, Fulton S, Nichol C, Reid M, Cheng X (2004) Hydrogeochemical and isotopic constraints on the origins of dry land salinity, Murray Basin, Victoria, Australia. Appl Geochem 19:1233-1254

Chadha DK (1999) A proposed new diagram for geochemical classification of natural waters and interpretation of chemical data. Hydrogeol J 7:431-439

Christian K, Avi D, Dodoo K, Kortatsi BK (2014) The hydrochemistry of groundwater in some communities in the Ayensu River basin in the central region of Ghana. J Environ Earth Sci 4(20):50-64

CITRA-SOGREAH-CCG-HYDRA (1965) Development and utilization of the groundwater resources in the Tabriz area and vicinity (report in French). East Azarbaijan Regional Water Authority, Tabriz

Currell MJ, Carthwright I (2011) Major-ion chemistry, $\delta^{13} \mathrm{C}$ and ${ }^{87} \mathrm{Sr} /{ }^{86} \mathrm{Sr}$ as indicators of hydrochemical evolution and sources of salinity in groundwater in the Yuncheng Basin, China. Hydrogeol J 19:835-850

Das S, Nag SK (2015) Application of multivariate statistical analysis concepts for assessment of hydrogeochemistry of groundwatera study in Suri I and II blocks of Birbhum District, West Bengal, India. Appl Water Sci. doi: 10.1007/s13201-015-0299-6

Domenico PA, Schwartz FW (1990) Physical and chemical hydrogeology. Wiley, New York, p 824

ELC-ELECTRO Consult (1969) Tabriz plain water development. East Azarbaijan Regional Water Authority, Tabriz

Emberger L (1930) Sur une formule applicable en ǵeographie botanique; Cah. Herb Seanc Acad Sci 191:389-390

Gibbs R (1970) Mechanism controlling world river water chemistry. Science 170:1088-1090

Gillardet J, Dupre B, Louvat P, Allegre CJ (1999) Global silicate weathering and $\mathrm{CO}_{2}$ consumption rates deduced from the chemistry of large rivers. Chem Geol 159:3-10

Hamed Y, Dassi L, Tarki M, Ahmadi R, Mehdi K, Ben Dhia H (2011) Groundwater origins and mixing pattern in the multilayer aquifer system of the Gafsa-south mining district: a chemical and isotopic approach. Environ Earth Sci 63(6):1355-1368

Han G, Liu C-Q (2004) Water geochemistry controlled by carbonate dissolution: a study of the river waters draining karst-dominated terrain, Guizhou province, China. Chem Geol 204:1-21

Hinkle SR, and Polette DJ (1999) Arsenic in ground water of the Willamette Basin, Oregon. USGS Water Resources Investigation Report 98-4205

Jafar Ahamed A, Ananthakrishnan S, Loganathan K, Manikandan K (2013) Assessment of groundwater quality for irrigation use in Alathur Block, Perambalur District, Tamilnadu, South India. Appl Water Sci 3:763-771

Jalali M (2009) Geochemistry characterization of groundwater in an agricultural area of Razan, Hamadan, Iran. Environ Geol 56:1479-1488

Kortatsi BK (2007) Hydrochemical framework of groundwater in the Ankobra Basin, Ghana. Aquat Geochem 13:41-74

Li P, Jianhua W, Hui Q (2013) Assessment of groundwater quality for irrigation purposes and identification of hydrogeochemical 
evolution mechanisms in Pengyang County, China. Environ Earth Sci 69:2211-2225

Lloyd J, Heathcote J (1985) Natural inorganic hydrochemistry in relation to groundwater. Oxford University Press, New York

Meybeck M (1987) Global chemical weathering of surficial rocks estimated from river dissolved leads. Am J Sci 287:401-428

Mokhtar MB, Aris AZ, Abdullah MH (2009) A pristine environment and water quality in perspective: Maliau Basin. Borneo's mysterious world. Water Environ J 23(3):219-228

Nagaraju A, Sunil Kumar K, Thejaswi A, Sharifi Z (2014) Statistical Analysis of the Hydrogeochemical Evolution of Groundwater in the Rangampeta area, Chittoor District, Andhra Pradesh, South India. Am J Water Resour 2(3):63-70. doi:10.12691/ajwr-2-3-2

Nagireddi Srinivasa Rao (2006) Nitrate pollution and its distribution in the groundwater of Srikakulam district, Andhra Pradesh, India. Environ Geol 51(4):631-645

Parkhurst LB, Appelo CAJ (1999) User guide to PHREEQC (version 3). A computer program for speciation, batch reaction, one dimensional transport, and inverse geochemical calculation. USGS WaterResources Investigation Report 99-4259, Washington DC, USA

Rajmohan N, Elango L (2004) Identification and evolution of hydrogeochemical processes in an area of the Palar and Cheyyar River Basin, Southern India. Environ Geol 46:47-61

Reghunath R, Murthy TRS, Raghavan BR (2002) The utility of multivariate statistical techniques in hydrogeochemical studies: an example from Karnataka, India. Water Res 36:2437-2442

Senthilkumar M, Elango L (2013) Geochemical processes controlling the groundwater quality in lower Palar river basin, southern India. J Earth Syst Sci 122(2):419-432

Shankar BS, Balasubramanya N, Reddy MMT (2008) Impact of industrialization on groundwater quality - a case study of Peenya industrial area, Bangalore. Environ Monit Assess 142:263-268

Sharma DRR, Rao SLN (1997) Fluoride concentration in groundwater of Vishakhapatanam, India. Bull Environ Cont Toxicol 58:241-247

Singh KP, Malik A, Mohan D, Sinha S (2004) Multivariate statistical techniques for the evaluation of spatial and temporal variations in water quality of Gomti River (India) — a case study. Water Res 38:3980-3992

Stallard RF, Edmond JM (1983) Geochemistry of the Amazon 2: the influence of the geology and weathering environment on the dissolved load. J Geophys Res 88:9671-9688

Stumm W, Morgan JJ (1996) Aquatic chemistry: chemical equilibria and rates in natural waters. Wiley, New York

Sutharsiny A, Pathmarajah S, Thushyanthy M, Meththika V (2012) Characterization of irrigation water quality of Chunnakam aquifer in Jaffna Peninsula. Tropical Agricultural Research 23(3):237-248

Tarki M, Dassi L, Hamed Y, Jedoui Y (2011) Geochemical and isotopic composition of groundwater in the Complex Terminal aquifer in southwestern Tunisia, with emphasis on the mixing by vertical leakage. Environ Earth Sci 64:85-95

Tlili-Zrelli B, Azaza FH, Gueddari M, Bouhlila R (2012) Geochemistry and quality assessment of groundwater using graphical and multivariate statistical methods. A case study: Grombalia phreatic aquifer (Northeastern Tunisia). Arab J Geosci 6(9):3545-3561

Tziritis E, Skordas K, Kelepertzis A (2016) The use of hydrogeochemical analyses and multivariate statistics for the characterization of groundwater resources in complex aquifer system. A case study in Amyros River basin, Thessaly, central Greece. Environ Earth Sci 75:339

Venkateswaran S, Vijay Prabhu M, Mohammed Rafi M, Vallel LK (2011) Assessment of groundwater quality for irrigational use in Cumbum Valley, Madurai District, Tamil Nadu, India. Nat Environ Poll Tech 10:207-212

Voutsis N, Kelepertzis E, Tziritis E, Keleprtsis A (2015) Assessing the hydrogeochemistry of groundwaters in ophiolite areas of Euboea Island, Greece, using multivariate statistical methods. J Geochem Explor 159:79-92

World Health Organization (WHO) (2011) Guidelines for drinkingwater quality. WHO Press, Switzerland 